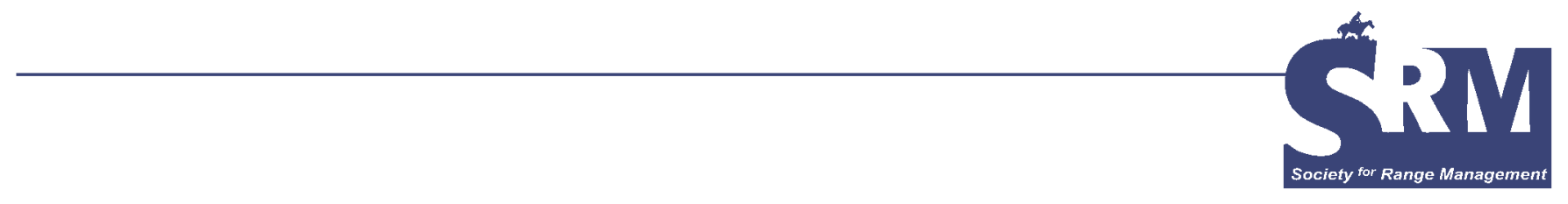

\title{
The United States Sheep Experiment Station: Shedding Light on Rangeland Ecosystems
}

\section{By Steven S. Seefeldt and William Laycock}

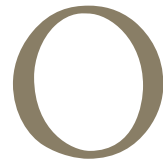

$\mathrm{n}$ a hike across the United States Sheep Experiment Station (USSES), you will likely see wooden stakes, rebar, fence posts, and angle iron. How did they get there? What is their story? Numbers are etched in the iron, attached to tags, or painted on the wooden stakes. What are they all about?

Rangeland scientists have been here and left their mark.

For over 80 years, research on rangelands has been conducted on the USSES, which is an important component of the US Department of Agriculture-Agricultural Research Service. The first president of the Society for Range Management, several charter members, and many other first-class scientists began their careers conducting research at the USSES (Table 1). The quality of research that has emerged is a reflection of those scientists' abilities and contributions. The long history of research, resulting in over 70 scientific publications, provides a foundation for understanding ecosystem processes and the consequences of management practices and disturbance.

\section{Land with Limited Water}

In 1915 President Woodrow Wilson signed the first of several land withdrawals from the public domain "for use by the United States Department of Agriculture as a sheep-breeding and grazing experimental station." Today 19,400 ha

This article has been peer reviewed.
$(47,942 \mathrm{ac})$ are assigned to the USSES and a further 15,970 ha $(39,471 \mathrm{ac})$ are leased from the Department of Energy, the US Department of Agriculture-Forest Service, and the Department of Interior-Bureau of Land Management. A newcomer to the spring/fall range will soon notice that there is very little water on the property, with only 1 ephemeral creek that runs along the western side. All water that is not utilized by plants or does not evaporate soaks into the ground and eventually reappears at Thousand Springs near Twin Falls, Idaho.

A water well, a few thousand sheep, and 10 fenced pastures were in place in 1925 when the first grazing experiments were initiated. Early experiments were designed to determine the influence of climate and the interaction of grazing on forage production. Although no longer relevant to modern grazing practices, ${ }^{1}$ the concept of range readiness was studied at the USSES. In one form or another, similar types of research are still being conducted on western rangelands. One of the first studies, measuring the effect of grazing seasonality on plant productivity and populations (Fig. 1 ), is the subject of 5 scientific papers. ${ }^{2-6}$ This study measured the damaging effects of heavy annual spring grazing and the beneficial effects of spring deferment and heavy fall grazing. This study is ongoing.

\section{Mountain Summers and Feedlot Winters}

Sheep management at the USSES is similar to standard sheep management practices in the Intermountain West 
Table 1. Range researchers who have worked at the US Sheep Experiment Station

\begin{tabular}{|l|c|c|}
\hline \multicolumn{1}{|c|}{ Scientist } & Organization & \multicolumn{1}{|c|}{ Year } \\
\hline C. L. Forsling & USFS & $1923-1930$ \\
\hline G. W. Craddock & USFS & 1930 \\
\hline G. D. Pickford & USFS & 1931 \\
\hline Joseph F. Pechanec & USFS & $1932-1945$ \\
\hline George Stewart & USFS & $1932-1945$ \\
\hline Clark E. Holscher & USFS & $1945-1949$ \\
\hline James P. Blaisdell & USFS & $1949-1954$ \\
\hline Walter F. Mueggler & USFS & $1954-1955$ \\
\hline Charles Wulstein & USFS & $1955-1957$ \\
\hline William A. Laycock & USFS & $1958-1961$ \\
\hline C. M. Cain & USFS & $1962-1964$ \\
\hline Henry A. Wright & USFS & $1964-1967$ \\
\hline Royal O. Harniss & USFS & $1967-1972$ \\
\hline Robert B. Murray & ARS & $1977-1986$ \\
\hline John Walker & ARS & $1988-1997$ \\
\hline John Hendrickson & ARS & $1998-1999$ \\
\hline Steven S. Seefeldt & ARS & $2000-2005$ \\
\hline Corey A. Moffet & ARS & $2005-p r e s e n t$ \\
\hline \begin{tabular}{l} 
USFS indicates US Department of Agriculture-Forest \\
Service; ARS, US Department of Agriculture-Agricultural \\
\hline Research Service.
\end{tabular} & \\
\hline
\end{tabular}

(Fig. 2). After early spring lambing, sheep graze new spring growth on the sagebrush steppe of the Upper Snake River Plain. Sheep move up to the Centennial Mountains on the Idaho-Montana border once the snows have melted. After late summer weaning, the sheep are moved from the mountains to lowlands for fall and early-winter grazing. Before the big winter snows arrive, the sheep are moved to a feedlot facility where they must be fed and later sheared.

Each of the sheep movements is to a different ecosystem, providing new opportunities for research. For example, studies have been conducted 1) on the summer range to determine the impacts of rest rotation; 2) on the spring/fall range to determine appropriate grazing strategies; 3 ) on winter grazing lands to determine sheep diet selection; and 4) on the feedlot to determine appropriate amounts and types of supplemental feed. Research on plant growth and development, lamb weight gains, and range utilization has been the subject of several scientific papers. ${ }^{7-9}$ Scientists have begun new research to deter- mine the impact of sheep bedding areas on the vegetation and soils in the Centennial Mountains (Fig. 3) and to measure water quality changes during stream crossings.

\section{Getting the Measure of Vegetation}

One of the most difficult problems in rangeland science and management in arid ecosystems is how to measure vegetation. There is an enormous amount of variability in vegetation that can be observed as one walks across the land. How extensive should the measurement plots be to account for vegetation variability? How many plots are needed to have confidence in the measurement? Do the size and number of plots need to change if plant species change? These questions and more have challenged rangeland scientists and managers ever since the question of whether grazing alters vegetation was first asked.

In 1938, Dr. Joseph Pechanec and George Stewart conducted landmark studies to determine the size and number of plots needed to measure vegetation with an acceptable degree of confidence. ${ }^{10-11}$ Using the newest statistical techniques and hand calculations (long division, square roots), they were the first to document the degree of sampling intensity needed to describe the vegetation and determine with confidence that scientific treatments alter vegetation. Use of the correct plot size and number of replicates is a lesson that, if ignored, will result in findings of no differences where differences actually exist. The widely used weightestimate method for estimating aboveground biomass was first developed and tested at the USSES. ${ }^{12}$ Recent research at the USSES is focused on using digital imagery to measure vegetation (Fig. 4), which has been determined to decrease the cost while increasing the precision of vegetation cover measurements. ${ }^{13}$

\section{Influence of Climate on Vegetation}

Given the inherent difficulties in measuring rangeland vegetation, how does a scientist or manager incorporate the addi-

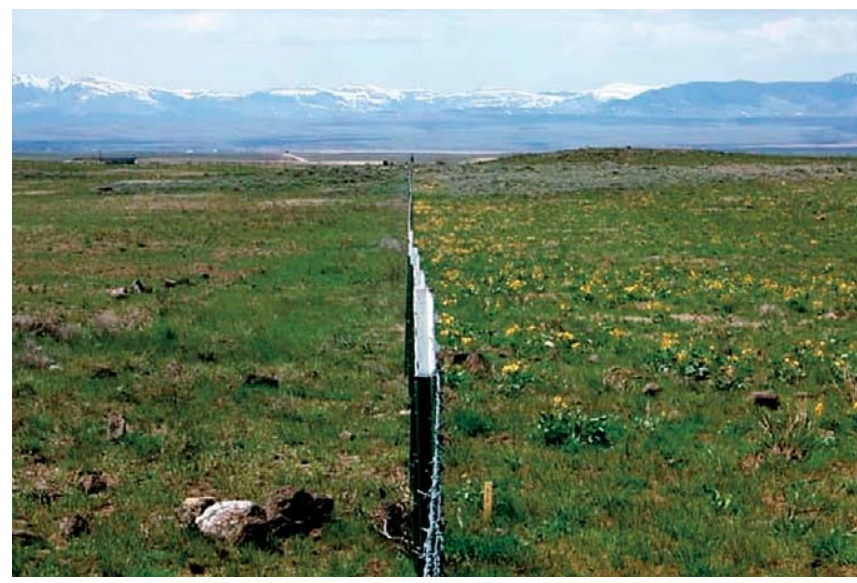

Figure 1. Fifty years of continuous spring grazing (left of fence line) and fall grazing (right of fence line) has resulted in significant change in vegetation populations. 


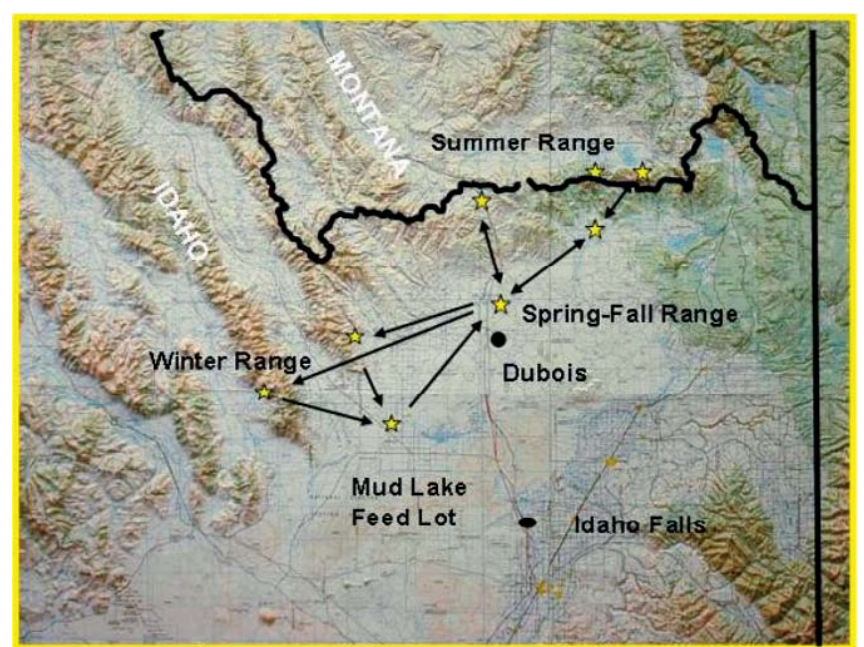

Figure 2. Seasonal sheep rotation at the US Sheep Experiment Station.

tional factor of climate on multiyear studies? One year the land can produce $600 \mathrm{~kg} / \mathrm{ha}(535 \mathrm{lb} / \mathrm{ac})$ of plant biomass, and the next year, depending on the climate, it can produce 3,000 $\mathrm{kg} / \mathrm{ha}(2,680 \mathrm{lb} / \mathrm{ac})$. How can this climatic impact be quantified, while at the same time accounting for changes in the vegetation as a response to scientific treatments or management? Was enhanced plant growth this year due to changes in management or well-timed rains?

Research at the USSES, starting in 1923 and continuing today, is designed to address this issue of climatic variation and vegetation response. A variety of permanent plots were established in the 1920s. Weather has been continuously monitored from 1923 to present. Research was conducted through the Dust Bowl years (mid-1930s) and provides information regarding recovery times for perennial grasses following drought. ${ }^{14}$ Additionally, the relationship between abundance of precipitation and annual growth of forage has also been examined at the USSES. ${ }^{15-16}$ The findings provide land managers with information essential to managing rangelands through climatic extremes common to the sagebrush steppe. Recently, funding is being secured to digitize historic maps and chart quadrats as the first step in determining how vegetation populations may have changed over time as a consequence of changes in the climate.

\section{Fire in Rangelands}

Fire is a controversial topic in the west and more quality research is needed to study the consequences of fire on the rangeland ecosystem. Fires are a naturally occurring phenomenon in the sagebrush steppe. Since humans have arrived, people have intentionally started fires for a variety of reasons. People have also suppressed fires to enhance wildlife habitat or protect property. Some prescribed fires have also been started at times of year when they don't occur naturally. How do these fires affect the ecosystem? What happens if fires are suppressed? Is there a natural fire cycle? Should pre-

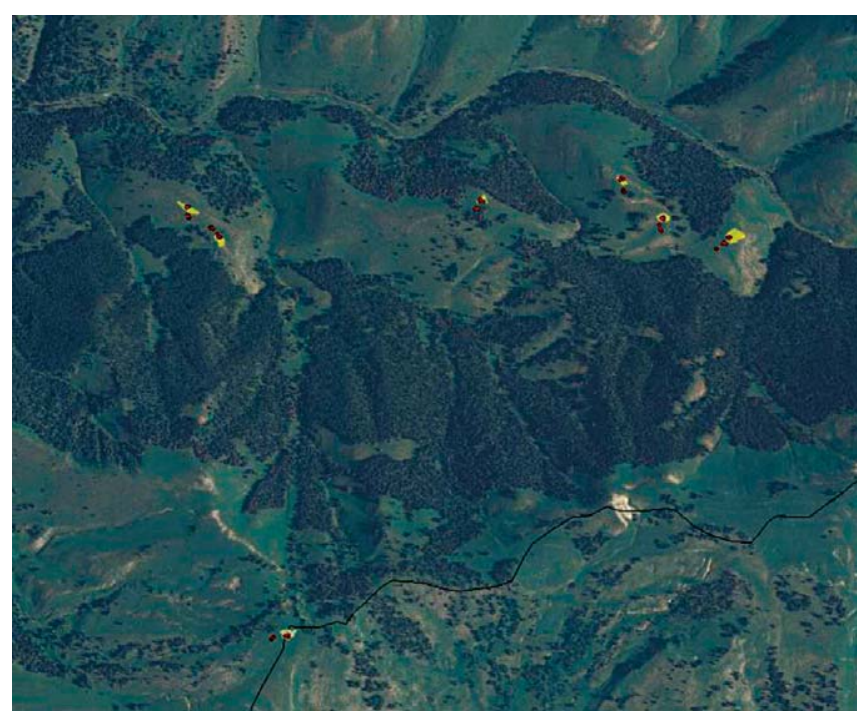

Figure 3. Sheep bed-down areas (yellow shapes) and sample points (red dots) on the US Sheep Experiment Station summer range.

scribed fires be allowed or prohibited? What about natural fires? How soon should grazing begin after fire?

At the USSES, key studies have been conducted to determine the consequences of fire. Some of the earliest research on using prescribed fire to control or reduce sagebrush was conducted at the USSES. Wildfires have burned across USSES land multiple times. Prescribed fires have been started at the USSES for both management and research purposes (Fig. 5). Pechanec and Stewart's 1944 publication $^{17}$ described one of the earliest studies outlining techniques for burning sagebrush. Because fires at the USSES have been well mapped, we know how frequently areas on the USSES have burned in the last 80 years, ranging from 0 to 5 times. Recovery of vegetation after fire was thoroughly documented for 37 years after a prescribed fire in 1932. The succession of vegetation after the fire has served as a benchmark for understanding vegetation recovery after fire in the sagebrush

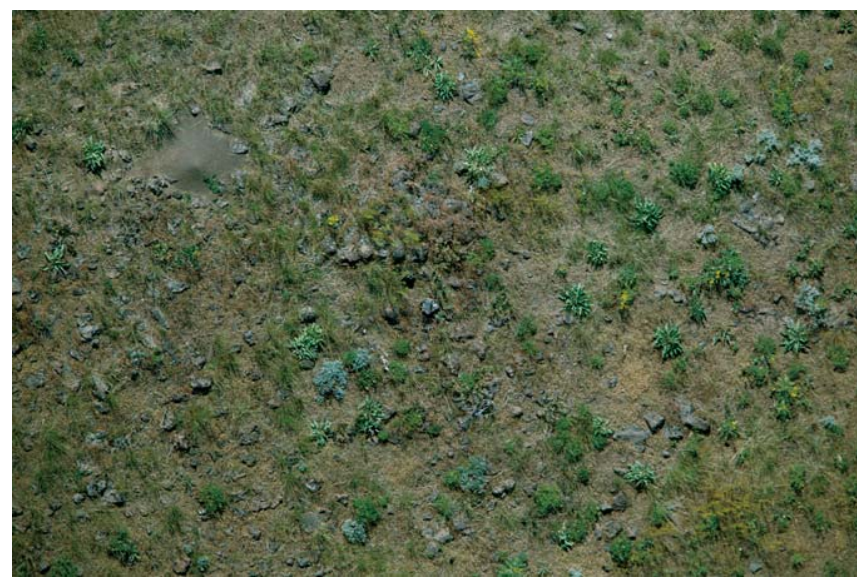

Figure 4. Digital image $(6-8 \mathrm{~m})$ of rangeland taken $100 \mathrm{~m}$ above ground level using a camera mounted on a 225-kg airplane 3 years after a wildfire on US Sheep Experiment Station property. 


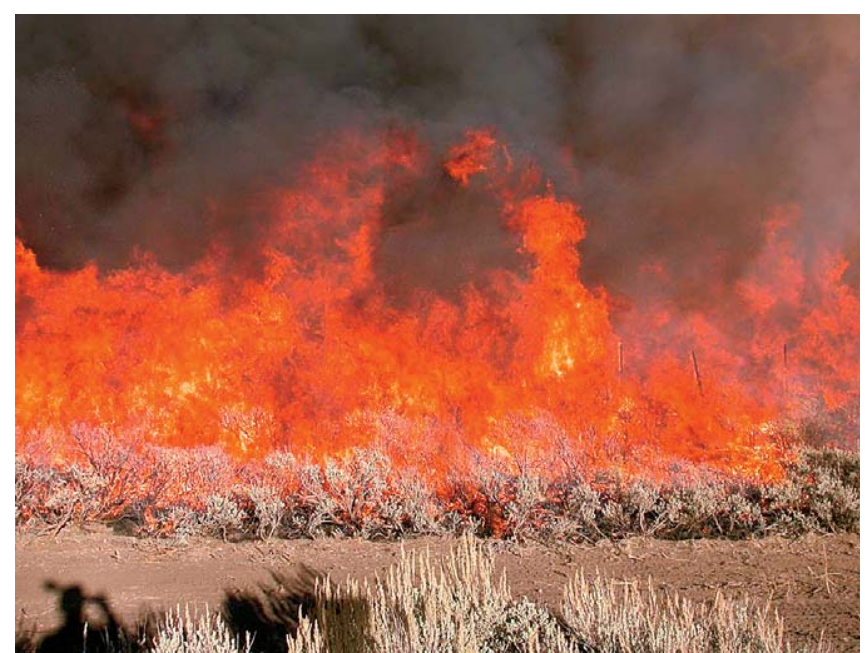

Figure 5. Prescribed fire in 2003 at the US Sheep Experiment Station.

steppe. ${ }^{18}$ Fire research is ongoing at the USSES, with fires being replicated in space and time and with particular attention given to before-fire vegetation (Fig. 6) in order to develop predictive models of vegetation response after fire based on vegetation condition before the fire.

\section{Exotic Weed Invasions in the West}

Exotic weed invasions are an important threat to native rangeland vegetation, soils, and economies. There are more than 20 exotic weed species involved and many additional exotic plant species that were initially planted to "improve" rangelands that may be added to the list. Why are these plants spreading so fast? Are chemicals the only control measure that is effective for managing them? What does plant diversity have to do with invasion susceptibility? Can grazing be part of the solution?

Downy brome was documented in the spring/fall range at the USSES in 1923. A vegetation map produced in 1938 shows a pasture that had been seeded to sunflower years earlier to be largely downy brome and Russian thistle. Although weed levels are low at the USSES, other exotic weeds have been moving into the Upper Snake River Plains more recently. North of the sheep station spring/fall range is an invasion of leafy spurge that has been the focus of research

\section{Plant names used in manuscript}

\begin{tabular}{|l|l|}
\hline Common name & Scientific name \\
\hline Downy brome & Bromus tectorum L. \\
\hline Russian thistle & Salsola iberica Sennen \\
\hline Leafy spurge & Euphorbia esula L. \\
\hline Spotted knapweed & Centauria maculosa Lam. \\
\hline Russian knapweed & Centauria repens L. \\
\hline
\end{tabular}

for over a decade. To the west is an invasion of spotted knapweed and to the south is an invasion of Russian knapweed. Some of these plants are classified as noxious weeds, but all are nutritious forage for sheep. Therefore, current research at the USSES is targeted at determining whether strategic sheep grazing can be used as a tool to contain weed populations, increase resistance of rangelands to invasion, and decrease the density of these exotic plant species (Fig. 7).

\section{Alternative Grazing Strategies}

Livestock grazing alters vegetation in predictable patterns based on type of animal, grazing season, and stocking rate and density (Fig. 1). With this in mind, is it possible to develop grazing strategies to improve rangeland vegetation? Can livestock grazing strategies be part of a restoration project? Will grazing strategies be developed to improve vegetation productivity and diversity? Can grazing strategies be developed to suppress exotic weeds and enhance native vegetation?

At the USSES, scientists are just beginning to document the impact of strategic grazing of exotic weeds on the associated native vegetation. If livestock graze exotic weeds when they are most susceptible to injury and if it is at a time when desired vegetation is resistant to grazing, then perhaps native vegetation may recover and outcompete exotic weeds. If the strategy works, people with weed-infested fields might be willing to pay livestock managers to have their weeds managed. Scientists at the USSES are conducting research to determine whether sheep productivity will be altered when consuming exotic weeds as a large portion of their diet. On the USSES summer range, a study is in progress to determine whether the spoil from an inactive mine can be revegetated using broadcast seeding followed by a band of 1,000 ewes and their lambs trampling the seed into the soil to improve germination (Fig. 8). At the USSES, all current grazing studies on the range include measures of vegetation

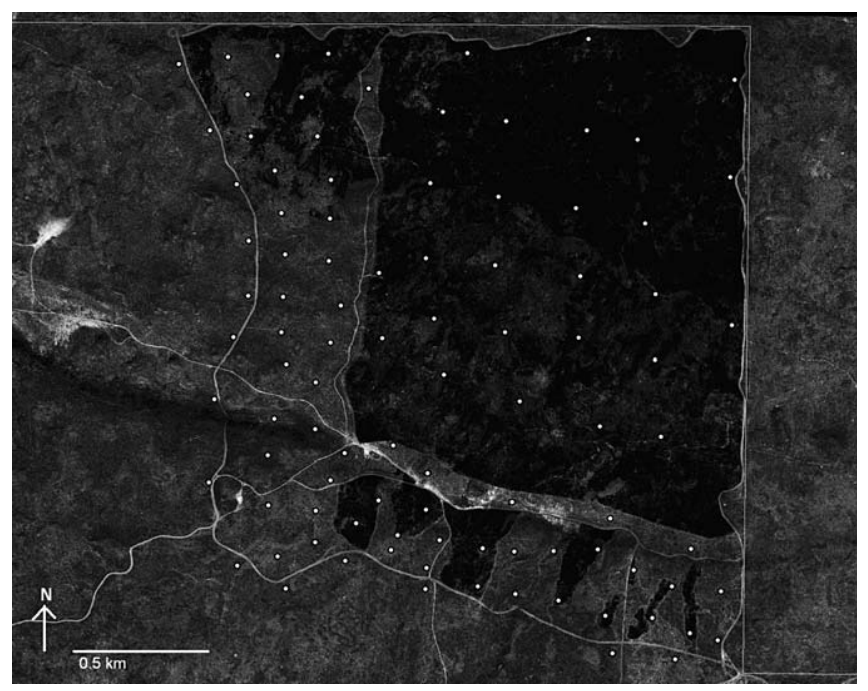

Figure 6. Quickbird satellite image of the 2002 fire study at the US Sheep Experiment Station. 
change, which will ultimately result in the development of additional science-based grazing strategies designed to move rangeland vegetation toward a desired goal.

\section{Future Directions and Building on the Base}

Where is rangeland science at the USSES heading? There are issues of rare and endangered species. There are political pressures to change rangeland use. At the USSES, efforts are made to predict future trends and attempt to be proactive while at the same time conducting excellent research.

New technologies are always being developed that have promise for improving rangeland measurement and management. These technologies are being tested in cooperation with other ARS scientists, and other federal agencies. With assistance from Idaho State University (Pocatello, ID), the USSES is entering all research information into a stationbased geographic information systems (GIS) database. This GIS database relates our research, animal-management strategies, soils, vegetation, fires, and climate to each other. Databases such as this are important in developing scientifically based predictions of what will happen to the sagebrush ecosystem if conditions such as management, climate, fire cycle, etc. are altered. Improved measurement methods (more precise and cost effective) will be used to document improvements to rangelands as a consequence of these alternative grazing strategies.

\section{Conclusion}

Rangeland vegetation will always be in a state of change. Plant communities respond in a variety of ways to disturbance, changing climates, and successional processes following fire. The rate of change in rangelands has increased because of the introduction and expansion of exotic plant species, increasing fragmentation of landscapes, alterations

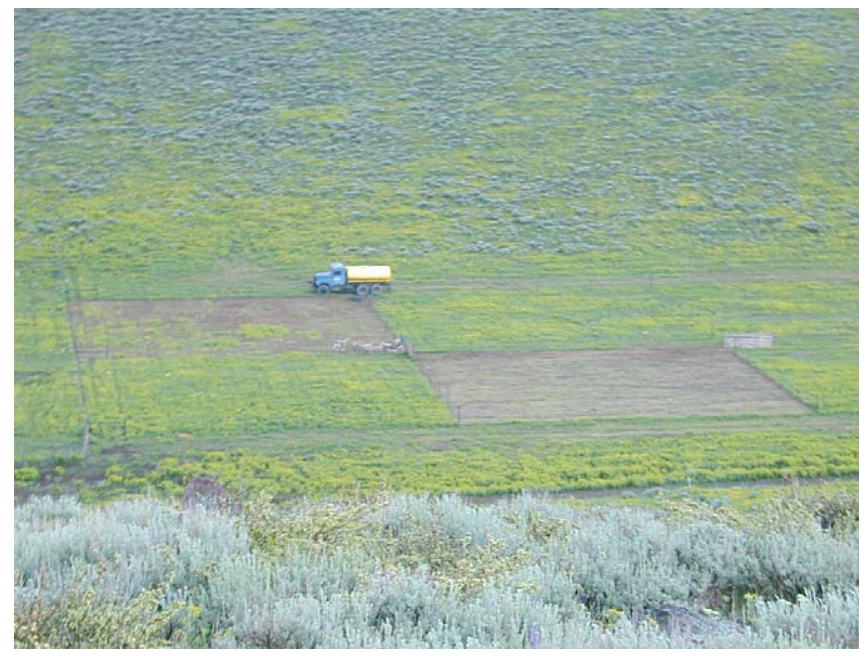

Figure 7. Portion of an experiment to determine if 1 or 2 years of strategic sheep grazing to prevent seed set in leafy spurge, followed with a fall application of imazapic (Plateau) will have a synergistic effect on reducing leafy spurge densities at a site north of the US Sheep Experiment Station.

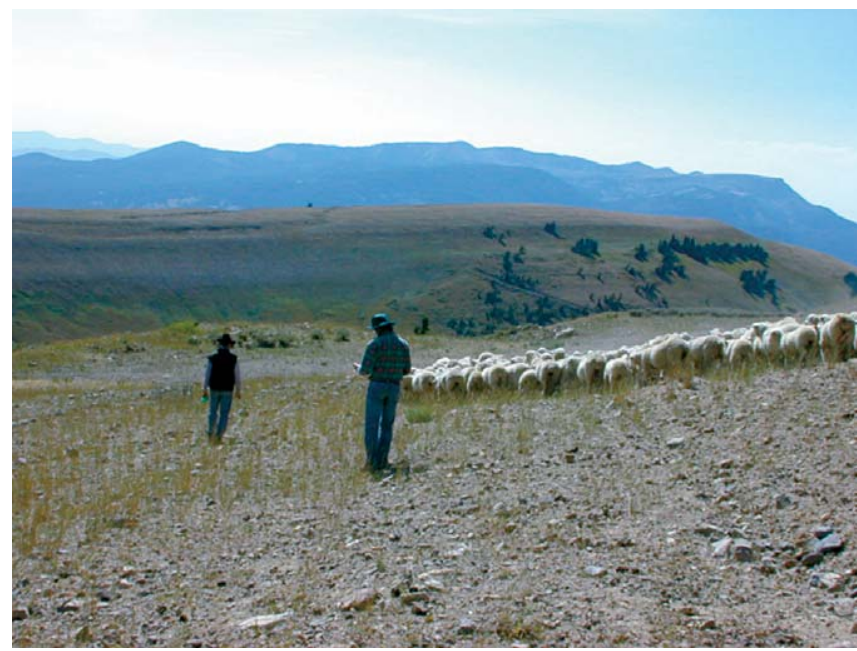

Figure 8. A band of ewes and their lambs are used to incorporate hand-sown seed on an old phosphate mine located in the summer range of the US Sheep Experiment Station.

of fire cycles, and expanding human populations. Despite all these changes, research at the USSES, with its long history of excellent science, is producing products that help scientists and land managers develop science-based strategies to maintain and improve our rangelands for generations to come.

Authors are Research Agronomist, USDA-ARS, Subarctic Agricultural Research Unit, Room 355 O'Neill Bldg, University of Alaska Fairbanks, Fairbanks, AK 99775, sseefeldt@ prw.ars.usda.gov (Seefeldt); and Certified Senior Ecologist, Rangeland Enterprises, Rangeland and Natural Resource Consulting, 3415 Alta Vista Drive, Laramie, WY 82072 (Laycock). At the time of research, the lead author was Rangeland Scientist, USDA-ARS United States Sheep Experiment Station, HC 62 Box 2010, Dubois, ID 83423. USDA Agricultural Research Service is an equal opportunity/affirmative action employer and all agency services are available without discrimination.

\section{References}

1. Perryman, B. L., W. A. Laycock, L. B. Bruce, K. K. Crane, AND J. W. BURKHARDT. 2005. Range readiness is an obsolete management tool. Rangelands 27:36-41.

2. Pechanec, J. F., AND G. Stewart. 1949. Grazing spring-fall sheep ranges of southern Idaho. Washington, DC: USDA Circular 808. 34p.

3. Mueggler, W. F. 1950. Effects of spring and fall grazing by sheep on vegetation of the Upper Snake River Plains. Journal of Range Management 3:308-315.

4. LAYCOCK, W. A. 1967. How heavy grazing and protection affect sagebrush-grass ranges. Journal of Range Management 20:206-213.

5. Bork, E. W., N. E. West, And J. W. Walker. 1998. Cover components on long-term seasonal sheep grazing treatments in three-tip sagebrush steppe. Journal of Range Management 51:293-300. 
6. Seefeldt, S. S., And S. D. McCoy. 2003. Measuring plant diversity in the tall threetip sagebrush steppe: influence of previous grazing management practices. Environmental Management 32:234-245.

7. Buchanan, W., W. A. Laycock, and D. A. Price. 1972. Botanical and nutritive content of the summer diet of sheep on a tall-forb range in southwestern Montana. Journal of Animal Science 35:423-430.

8. Krueger, W.C., W.A. Laycock, And D.A. Price. 1974. Three methods for determining diet, utilization, and trampling damage on summer range. Journal of Range Mangement 27:258-262.

9. Harniss, R. O., AND H. A. Wright. 1982. Summer grazing of sagebrush-grass range by sheep. Journal of Range Mangement 35:13-17.

10. Pechanec, J. F., And G. Stewart. 1940. Sagebrush-grass range sampling studies: size and structure of sampling unit. American Society of Agronomy Journal 32:669-682.

11. Pechanec, J. F., And G. Stewart. 1941. Sagebrush-grass range sampling studies: variability of native vegetation and sampling error. American Society of Agronomy Journal 33:1057-1071.
12. Pechanec, J. F., And G. D. Pickford. 1937. A weight-estimate method for determination of range pasture production. Journal of the American Society of Agronomy 29:894-904.

13. SeefeldT, S. S., And D. T. Booth. 2005. Measuring plant cover in sagebrush steppe rangelands: A comparison of methods. Environmental Management 37 (in press).

14. Pechanec, J. F., G. D. Pickford, and G. Stewart. 1937. The effects of the 1937 drought on native vegetation of the Upper Snake River Plains. Ecology 18:490-505.

15. Blaisdell, J. P. 1958. Seasonal development and yield of native plants on the Upper Snake River Plains, and their relation to certain climatic factors. Wasington, DC: USDA Technical Bulletin 1190. 68p.

16. Craddock, G. W., AND J. E. Forsling. 1938. The influence of climate and grazing on spring-fall sheep range in southern Idaho. Washington, DC: USDA Agricultural Technical Bulletin 600. 43p.

17. Pechanec, J. F., And G. SteWART. 1944. Sagebrush burning - good and bad. Washington, DC: USDA Farmers Bulletin 1948. 32 p.

18. Harniss, R. O., AND R. B. Murray. 1973. 30 years of vegetal change following burning of sagebrush-grass range. Journal of Range Management 26:322-325. 